This document is the accepted manuscript version of the following article: Rehush, N., \& waser, L. T. (2017). Assessing the structure of primeval and managed beech forests in the Ukrainian Carpathians using remote sensing. Canadian Journal of Forest Research, 47(1), 63-72. https://doi.org/10.1139/cjfr-2016-0253

\title{
Assessing the structure of primeval and managed beech forests in the Ukrainian
}

\section{Carpathians using remote sensing}

\author{
Nataliia Rehush ${ }^{1,3}$, Lars T. Waser ${ }^{2}$
}

${ }^{1}$ Department of Forest Resources and Management, Swiss Federal Institute for Forest, Snow and Landscape Research WSL, Zürcherstrasse 111, 8903 Birmensdorf, Switzerland.

Email: nataliia.rehush@wsl.ch

${ }^{2}$ Department of Landscape Dynamics, Swiss Federal Institute for Forest, Snow and Landscape

Research WSL, Zürcherstrasse 111, 8903 Birmensdorf, Switzerland. Email: waser@wsl.ch

${ }^{3}$ Department of Forest Inventory and Management, Ukrainian National Forestry University, Generala Chuprynky str. 103, 79057 Lviv, Ukraine.

Corresponding author: Nataliia Rehush

Email: nataliia.rehush@wsl.ch

Phone: +41447392552 


\section{Abstract}

2 Forest structure reflects the forest disturbance regime, and can provide important information about

3 the rate of human impact. A better understanding of the structural variability and large-scale

4 dynamics of natural forests is crucial for "close-to-nature" forest management planning. In this

5 study, we developed a partly automated approach to assess the structure of potential primeval and

6 managed beech forests in the Ukrainian Carpathians using WorldView-2 imagery. We analyzed the

7 local $(50 \times 50 \mathrm{~m}$ scale $)$ canopy closure of these forests by extracting the canopy gaps, and

8 determined four forest structure types ranging from very closed to low density. The occurrence and

9 frequencies of these structure types were significantly different in the primeval and managed beech

10 forests. The four forest structure types were predicted and mapped using multinomial logistic regression based on the textural features derived from the original image bands and two vegetation indices. A 10 -fold cross-validation resulted in an overall accuracy of $83 \%$ and a kappa coefficient of $75 \%$, with the highest agreement for the very closed structure type (87\%) and the lowest for the medium and low density (79\%). The forest structure type maps can be helpful for planning management activities in beech forests.

Keywords: beech forests, structure types, canopy gap fraction, WorldView-2, Carpathian region. 


\section{Introduction}

Beech forests are a potentially natural vegetation type in European temperate forests, and one of the dominant forest ecosystems in the Carpathian mountain region. In the Ukrainian Carpathians, beech forests cover $35 \%$ of the forest area and are economically and ecologically important. Currently, forestry in the Ukraine has to cope with the competing demands of obtaining a good economic return, adapting to changing environmental conditions, and remaining sustainable in terms of the forests ecological, economic and social functions. "Close-to-nature" forest management should conceptually meet these requirements, but its development needs information on the functionality and dynamics of natural forests. Such forest ecosystems, e.g. primeval forests, which have been influenced only by natural disturbances, therefore serve as references for "close-to-nature" forest management planning (Korpel' 1995; Meyer and Schmidt 2008), but they are rare and mostly located in rather inaccessible regions. Most of the forests in the Ukrainian Carpathians have been intensively used since around 1900. Nevertheless, a few areas of beech forest that have never been influenced substantially by humans have been preserved (Commarmot et al. 2013; Brändli and Dowhanytsch 2003).

Disturbances are a driving force for forest stand development and affect forest structure. European national forest inventories (NFIs) therefore use forest structure as one of their criteria for assessing naturalness (McRoberts et al. 2012). Natural beech forests are mostly affected by small-scale disturbances, i.e. the fall of a single tree or of a few neighboring trees (Drößler and Lüpke 2005; Hobi et al. 2015), and thus stand structural features (e.g. stem density, basal area) have a high local variability (Král et al. 2010; Alessandrini et al. 2011). To assess the spatial heterogeneity and dynamics of natural beech forests, the "forest cycle" concept (Watt 1947) has been variously adapted (e.g., Korpel' 1995; Tabaku 2000). However, in-depth knowledge on the large-scale dynamics of natural beech forests is still limited. Moreover, previous studies have mainly focused on relatively small areas (e.g., Meyer and Schmidt 2008), and NFI programs rarely include funding for the costly additional work of surveying stand structures over large areas (Barrett et al. 2016). 
Assessing forests' structural conditions is thus an important application of remote sensing (Frolking et al. 2009). Recent technological developments in LiDAR (Light Detection and Ranging) and VHR (very high resolution) remote sensing have opened up new opportunities for supplementing NFI programs (Barrett et al. 2016). It is, as result, now possible to obtain precise and up-to-date information on the complexity of the forest structure over large areas (Coops et al. 2006).

LiDAR has great potential for characterizing forest succession (Falkowski et al. 2009), assessing such vertical forest structure parameters as canopy height, stand foliage (Korhonen et al. 2011; Mura et al. 2015) and canopy gap characteristics (Vepakomma et al. 2008). VHR multispectral satellite imagery (Ozdemir and Karnieli 2011) and airborne imagery (Pasher and King 2010) are also used to assess and map forest structures, but they do not directly provide canopy height parameters. The missing vertical information can either be compensated by analyzing image texture (Wood et al. 2012; Coburn and Roberts 2004) or by analyzing the patterns and fractions of shadows and gaps (Leboeuf et al. 2007). Remote sensing data have been used in recent years to analyze canopy gaps and their distribution (patterns) in sub-tropical forests (Kennaway et al. 2008), boreal forests (Rich et al. 2010), Carpathian beech forests (Hobi et al. 2015), and European mountain forests (Rugani et al. 2013; Torresan et al. 2014).

The heterogeneity of the canopy cover is given by the fraction of crowns and shadows, with the shadow fraction representing the gaps and shaded parts of the crowns. The forest structure and gap dynamics of old-growth beech forests have been mostly assessed by analyzing the patterns, sizes, and depths of gaps in terrestrial sampling data (e.g., Meyer and Schmidt 2008). However, to date few studies (e.g., Garbarino et al. 2012; Getzin et al. 2014; Hobi et al. 2015) have analyzed crown and canopy gap properties to characterize beech forests using VHR optical imagery exclusively.

The objective of the present research was to design a partly automated approach to assess and map the structure of potential primeval and managed beech forests in the Ukrainian Carpathians using WorldView-2 data. Assessing the differences in the structure of managed and primeval beech forests can provide important information for managing beech forests sustainably, as well as for 
71

detecting and mapping potential primeval beech forests. The study's findings and methodology should also be relevant for the Ukrainian State Forest Management Planning Organization (SFMPO) especially for evaluating inaccessible parts of beech forests. This study also describes limitations when using optical VHR imagery, in particular, in areas with complex topography. Transferability of these assessment methods to similar regions, as well as their pros and cons, alternative sensors and ways of handling their limitations are also discussed.

\section{Materials}

\subsection{Study area}

The study area is located in the southwest Ukraine (Figure 1, left) and covers approx. $40 \mathrm{~km}^{2}$, of which $90 \%$ are forest, and $10 \%$ pastures with a few single settlements. Geographically, the study area is situated in the upper part of the Borzhava river $\left(48^{\circ} 36^{\prime} \mathrm{N}, 23^{\circ} 15^{\prime} \mathrm{E}\right)$ and belongs to the Ukrainian Carpathians, with an elevation ranging from 450 to $1400 \mathrm{~m}$ above sea level with an upper tree border at 1100-1200 m a.s.l. According to the closest meteorological station (Play, $1343 \mathrm{~m}$ a.s.1.), the climate is temperate continental with a mean annual precipitation of $1753 \mathrm{~mm}$ and a mean annual air temperature of $2.6^{\circ} \mathrm{C}$. Parent substrate consists of slide rocks of sandstone and shale covered with brown earth soil. The dominant (93\%) tree species is beech (Fagus sylvatica L.), and the most common non-dominant species are Norway spruce (Picea abies (L.) H.Karst.) and maple (Acer sp.).

Intensive use of the wood resources in the forests in the study area started approx. 70 years ago. According to Roth (1932), the forests in the upper part of the Borzhava river were defined as primeval beech forests because of very limited human impact and high structural variability. These forests were privately owned in the 1930s and were only occasionally used for hunting. Only the narrow belts along the forests adjacent to alpine meadows (approx. $100 \mathrm{~m}$ wide) and to grassland in the lower parts (100-300 m wide) were used to a limited extent for wood products (Roth 1932). Since the 1950s these forests have belonged to the state forest enterprise and have mostly been 
managed by clear-cutting. Nowadays, only the forests with a protection function above $800 \mathrm{~m}$ a.s.1. are recognized as being primeval beech forests (Chernyavskyy and Khmil 1998). The even-aged forests with a mean age of $\leq 60$ years in the lower parts of the study area are the result of extensive clear-cutting.

\subsection{Remote sensing data and pre-processing}

A WorldView-2 scene was acquired on 17 June 2012, ordered as LV2A multispectral (MS) and panchromatic (PAN), with spectral information coded in units of digital numbers (DN). Detailed information about the acquisition parameters is given in Table 1.

The original WorldView-2 image was converted to top-of-atmospheric (TOA) reflectance prior to spectral analysis as Updike and Comp (2010) recommended. It was then pan-sharpened by fusing the coarse spatial resolution data with the higher spatial resolution panchromatic band using the Gramm-Schmidt multispectral sharpening (Jawak and Luis 2013). Finally, the $0.5 \mathrm{~m}$ pan-sharpened multispectral image was orthorectified using a digital terrain model (DTM) from the Shuttle Radar Topography Mission (SRTM) and five ground control points (GCP) measured during a field survey using Trimble Geoexplorer XH 2005. The STRM DTM was stepwise resampled from $90 \mathrm{~m}$ to $2 \mathrm{~m}$. The orthorectification revealed a root-mean-square deviation (RSME) of 0.35 pixels. Since the focus of this study was on a monotemporal analysis, the failure of the topographic and radiometric corrections was not critical. The pan-sharpened orthorectified WorldView-2 image with a spatial resolution of $0.5 \mathrm{~m}$ converted to TOA reflectance served as a basis for all investigations in the study.

\subsection{Reference data}

\subsubsection{Stand maps and descriptions}

The stand maps and descriptions were updated in 2010 by the Ukrainian SFMPO, which is responsible for the forest inventory, monitoring and forest management planning. The stand maps 
123

consist of digitalized and georeferenced forest taxation units. These units are parts of forests, which have homogeneous stand parameters and scheduled management activities (Instructions for forest management planning in Ukraine 2006). Detailed information about the stand parameters in the forest taxation units is given in the forest stand descriptions. The stand parameters include tree species composition, mean stand age, mean DBH, mean stand height, timber volume per 1 ha, number of stand layers, stand's origin (natural or planted), regeneration abundance, and scheduled forest management activities. Both the forest stand descriptions and maps are updated every 10 years according to the national forest management planning strategy.

The forest stand maps and descriptions of the Svaliavske State Forest Enterprise were used to determine the test areas (Figure 1, right), which do not necessarily correspond one-to-one with forest taxation units. If the neighboring forest taxation units had very similar stand parameters (i.e., similar mean stand age, mean $\mathrm{DBH}$, mean height, and relative density), they were included in the same test area, i.e. the forest stands in one test area are homogenous regarding their stand parameters.

A total of 19 test areas were selected, based on the forest stand maps from SFMPO, to analyze the structure of the beech forests with different stand parameters (Figure 1, right). Slopes with an exposition between $120^{\circ}-220^{\circ}$, and thus less close to the nadir, were excluded from the investigations due to the complex topography of the study area and the large viewing angle of the satellite during the acquisition of the WorldView-2 imagery (see Table 1). The 19 test areas were aggregated into three forest groups according to their mean stand age: potential primeval (hereafter - primeval) forests with a mean age of 220 years, old-growth forests with a mean age ranging from 160 to 190 years, and middle-aged forests with a mean age ranging from 35 to 60 years (Table 2).

\subsubsection{Field survey}

Ground reference data was collected during the summer 2012 in 8 field survey areas (Figure 1, right), each approx. 0.25 ha in size. In each area the diameter at breast height, tree height, tree 
149

150

151

152

153

154

155

156

157

158

159

160

161

162

163

164

165

166

167

168

169

170

171

172

173

174

vitality, and tree species were recorded for all trees with diameter at breast height $(\mathrm{DBH}) \geq 6 \mathrm{~cm}$.

The location of the trees was obtained directly by measuring the azimuth, horizontal distance, and vertical angle. Each tree was classified as belonging to one of the three canopy layers according to the IUFRO classification: upper layer - trees greater than $2 / 3$ of the dominant height; middle layer trees between $>1 / 3$ and $\leq 2 / 3$ of the dominant height; lower layer - trees shorter than $1 / 3$ of the dominant height. All field survey areas were georeferenced using Trimble Geoexplorer XH 2005. The reproduced tree stem positions and canopy layers were used to verify the canopy gap extraction using remote sensing data (see section 3.1).

\section{Methods}

The methodological workflow to assess the beech forest structure consisted of three main steps: 1) canopy gap extraction, 2) structure type determination, and 3) structure type mapping (Figure 2).

\subsection{Canopy gap extraction}

To assess the structural heterogeneity of the beech forests in the study area, canopy gaps were first identified on the WorldView-2 image. The canopy gaps were recognized as shadowed parts in the canopy cover, which correspond to canopy openings with a depth more than $1 / 3$ of the forest stand height. Prior to extracting the canopy gaps, canopy cover (excluding coniferous forest stands) was masked using the band ratio G/B and Normalized Difference Vegetation Index (NDVI). The color space transformation of the image bands red edge, yellow and blue into Hue, Lightness and Saturation (HLS) was then applied to separate canopy gaps (shadows) from tree crowns (sun-lit areas) in the previously generated canopy cover. Empirical tests revealed that all pixels with a Lightness value $\leq 0.15$ belong to canopy gaps, and those with a Lightness value $>0.15$ to tree crowns. This threshold value was validated on the field survey areas by reproducing the tree stem positions and canopy layers, and checking for correspondence with the canopy openings more than $1 / 3$ of the forest stand height in depth. 
175 For the following investigations, only canopy gaps greater than $10 \mathrm{~m}^{2}$ in area were selected. This 176 minimal canopy gap size was chosen for two methodological reasons. First, the small canopy gap 177 size substantially reduces the misclassification of the shadows within a tree crown as canopy gaps. 178 Second, the minimal canopy gap size of $10 \mathrm{~m}^{2}$ enabled the parts of old-growth and primeval beech forest stands with dense canopy cover to be separated from middle-aged forest stands. Moreover, a previous analysis of the frequency distributions of the canopy gaps identified had shown that around $65 \%$ of the canopy gaps in the old-growth and primeval forests are smaller than $50 \mathrm{~m}^{2}$, and approx. $40 \%$ are smaller than $25 \mathrm{~m}^{2}$. Such small canopy gaps can be considered as belonging to the textural attributes of the canopy cover in these beech forests.

The correlations between the canopy gap fractions and the forest stand parameters from the forest management descriptions in the test areas and those measured in the field for field survey areas were then tested using the Spearman correlation coefficient. A two-tailed $t$-test was performed to determine the significance level of the correlations. For each of the 19 test areas and 8 field survey areas, canopy gap fractions were derived as the ratio of the canopy gap area to the total area.

\subsection{Structure type determination}

To determine the forest structure types, we analyzed the spatial patterns of the canopy gaps in the 19 test areas using a regular grid with a cell size of $50 \times 50 \mathrm{~m}$. The choice of cell size was influenced by the morphological properties of tree crowns and canopy gaps in beech forests. The gaps in the canopy cover of beech forests are usually the result of small-scale disturbances (the fall of a single tree or of a few neighboring trees). Most of the canopy gaps in Europe's primeval beech forests are smaller than 200-250 $\mathrm{m}^{2}$, whereas canopy gaps over an area of 500-1000 $\mathrm{m}^{2}$ and larger are rare (Drößler and Lüpke 2005; Hobi et al. 2015). The morphology of beech crowns varies depending on their growth conditions, and in particular on the competing vegetation. Whereas a single tree crown in forest stands with $100 \%$ crown closure may cover an area of $200 \mathrm{~m}^{2}$, that of a solitary tree in open landscape may be as much as $700 \mathrm{~m}^{2}$ (Uhl et al. 2006). 
201 Based on these maximal canopy gap and tree crown sizes, a regular grid with a cell size of $50 \times 50$

$202 \mathrm{~m}$ seems to be the most appropriate to reduce the local variability of the forest structure and avoid

203 analyzing only single tree crowns or single canopy gaps. For each of the total of 716 grid cells in

204 the 19 test areas, the fraction of the canopy gaps was calculated as the ratio of the canopy gap area

205 to the total cell area (see Figure 3 for an example of a test area). The gap fraction distributions were

206 analyzed to assess the spatial heterogeneity of the canopy cover for primeval, old-growth, and

207 middle-aged beech forests (see Figure 4A-C). Based on the frequency distributions, four structure

208 types were defined: very closed (gap fraction 0\%), closed (gap fraction $0.1 \%$ to $10 \%$ ), medium

209 density (gap fraction $10.1 \%$ to $20 \%$ ), and low density (gap fraction $>20 \%$ ) (Table 4 ). The

210 Kolmogorov-Smirnov criterion (Smirnov 1939) was used to test the hypothesis that the

211 distributions of the forest structure types in the beech forest groups are statistically different.

212

213

\subsection{Structure type mapping}

\section{3.3.1. Image feature extraction}

215 The image feature extraction included three main steps. First, a set of spectral features from the

WorldView-2 image was generated (Table 3). In addition to the original bands, the NDVI was

calculated as an indicator of the photosynthetic activity of the vegetation (Rouse et al. 1973), and the Green Normalized Difference Vegetation Index (GNDVI) due to its higher sensitivity to chlorophyll concentrations (Gitelson and Merzlyak 1998).

Second, a Grey-Level Co-Occurrence Matrix (GLCM) was applied to examine the image texture statistically (Haralick 1973). GLCM-based features are frequently used to assess vegetation (Wood et al. 2012) and forest structure (Pasher and King 2010), as well as to extract stand parameters (e.g., Eckert 2012; Kayitakire et al. 2006; Ozdemir and Karnieli 2011). Based on these studies, eight

GLCM textural features were selected: mean, variance, homogeneity, second moment, contrast, correlation, entropy, and dissimilarity. These textural features were calculated on the eight original 
227

228

229

230

231

232

233

234

235

236

237

238

239

240

241

242

243

244

245

246

247

248

249

250

251

252

approach with a window size of $101 \times 101$ resampled image pixels. In total, 80 textural features were produced. The window size corresponds to the size of the field survey areas. All calculations of the textural features were performed in the R software environment using the package $\mathrm{glcm}$.

Third, a multicollinearity test was conducted for all 80 textural features using the vifstep function from the R package $u s d m$. Variables that correlated highly with a variance inflation factor (VIF) $>10$ were excluded from the set through a stepwise procedure (Neter et al. 1996). The remaining 15 textural features were then used as explanatory variables to predict the forest structure types.

\subsubsection{Structure type classification}

First, a Linear Discriminant Analysis (LDA) from the R package $M A S S$ was performed to reduce the variable space dimension and thus the redundancy and intercorrelation among the 15 textural features (Waser et al. 2014). LDA is a supervised statistical method, which allows the samples to be classified by analyzing a set of descriptors (Everitt and Dunn 2001). It is typically used as a feature extraction step before classification. The aim is to find the optimal discriminant vectors (transformation) by maximizing the ratio of the between-class distance to the within-class distance, thus achieving a maximum class discrimination.

Second, a multinomial logistic regression model was used to classify the four forest structure types. Multinomial logistic regression is a simple extension of binomial logistic regression that allows the response variable to have more than two categories, where one (in this case the forest structure type) is chosen as the comparison category. The probability of categorical membership was evaluated by maximum likelihood estimates (for details, see Hosmer and Lemeshow 2000). The resulting 716 grid cells were assigned to the forest structure type with the highest modeled probability. For the modeling, the multinom function implemented in the R package nnet was used.

Third, the predictive power of the model was verified with ten-fold cross-validations. The statistical measures used to validate the classification results were: producer's and user's accuracy, overall accuracy, and Cohen's kappa coefficient (see e.g., Richter et al. 2012). 
254

255

256

257

258

259

260

261

262

263

264

265

266

267

268

269

270

271

272

\section{Results}

\subsection{Canopy gaps}

The canopy gap fractions in the beech forests and in the forest groups vary substantially. In potential primeval forests, gap fractions range from $3.3 \%$ to $14.0 \%$, compared to from $1.9 \%$ to $10.0 \%$ in old-growth forests. The lowest gap fractions $(<1 \%$ or absent $)$ are found in middle-aged beech forests.

The proportions of canopy gaps in the test areas are highly correlated with all main forest stand parameters from the Ukrainian SFMPO (Table 5). Canopy gap fractions were found to be positively correlated with mean age, mean $\mathrm{DBH}$, mean height and volume at 0.001 and 0.01 significance levels. The canopy gap fractions correlated negatively with relative density at 0.05 significance level.

The proportion of canopy gaps in the field survey areas are significantly correlated with mean DBH only (Table 6). In contrast to the test areas, no significant correlations with mean height, tree density and volume were found.

\subsection{Forest structure types}

\subsubsection{Frequency distribution}

The frequency distributions of the four forest structure types very closed, closed, medium density and low density are shown for primeval, old-growth, middle-aged beech forests in Figure 4D. According to the Kolmogorov-Smirnov-criterion, the distributions are significantly different from each other at 0.001 level. In the middle-aged beech forests most stands $(80 \%)$ have a very closed structure type (no gaps). The remaining $20 \%$ have a closed structure with a low fraction of canopy gaps $(0.1 \%-10 \%)$. No medium or low density forest structure types were found.

For both old-growth and primeval beech forests, the percentages of stands with a very closed structure are low $(<5 \%)$. Old-growth beech forests are dominated by stands with closed structure 
279 (65\%), followed by medium density (25\%), and low density (5\%) stands. In contrast, the primeval 280 forests are characterized by forest stands with higher canopy gap fractions. Over 55\% of the forest 281 stands have a medium or low density structure. In the primeval forests, $14 \%$ of the stands have a low 282 density structure with a canopy gap fraction greater than $20 \%$. This fraction is three times as high as 283 that in the old-growth beech forests.

284

\subsubsection{Classification}

The classification of the four forest structure types based on 716 samples produced an overall accuracy of $83 \%$ and a Cohen's kappa coefficient of 75\% (Table 7). The very closed structure type was classified most accurately with a producer's accuracy of $87 \%$, followed by the closed (84\%), medium density (79\%), and low density (79\%) structure types. Misclassifications mostly occurred between adjacent classes of the four structure types, i.e. some very closed structure types were misclassified as closed structure types, and some low density structure type as medium density structure types.

\subsubsection{Predictive mapping}

The forest structure type map generated for the masked canopy cover using the classification model (see Table 7) was visually inspected and compared with the entire WorldView-2 orthoimage. To illustrate this, Figure 5 shows the predicted map of the forest structure types for one part of the study area. Visual inspection of those test areas where the stand parameters were derived from the forest stand descriptions from SFMPO confirmed that the four structure types are generally well classified.

Primeval beech forests are characterized by a high mixture of forest structure types. For the corresponding test areas, some parts were predicted to have medium density stands, and large parts to have stands with low density structure. It was predicted that the stands with closed structure would only be found in small isolated parts of the test areas, and that the very closed stands would 
305

be even rarer. The closed structure type was, however, dominant in one test area with old-growth beech forests. In the old-growth beech forests, the closed and medium density structure types were predicted to be dominant, and areas with low density or very closed forest stands were rare. In the middle-aged beech forests, very closed structure types were correctly predicted to be dominant, and only a few parts with closed stands were detected. Medium and low density structure types were rare.

\section{Discussion}

\subsection{Image data and pre-processing}

WorldView-2 satellite imagery seems to be suitable for assessing the structure of beech forests, but its potential is limited by the specific properties of VHR optical remote sensing data, i.e. sensitivity to the angles of the sun and sensor, as well as terrain complexity (see as well in Frolking et al. 2009, Hobi et al. 2015, Rugani et al. 2013). A high-quality and high-resolution DTM is required to conduct topographic and radiometric corrections of VHR imagery (Richter et al. 2009). In our study, the lack of a high-quality DTM together with the topographic complexity of the study area affected the pre-processing of the remote sensing data. The only alternative was to use the resampled $90 \mathrm{~m}$ spatial resolution DTM from the SRTM mission. Furthermore, it was difficult to collect a large number of GCPs with small errors due to the high proportion of forest cover in combination with complex terrain in the study area.

It was impossible to delineate canopy gaps and map the forest structure types on the entire WorldView-2 imagery due to the limitations of VHR optical remote sensing data. To ensure the analysis was reliable, the forest structures were assessed only in those parts of the study area that were closer to the nadir. On the slopes with an exposition of $120^{\circ}-220^{\circ}$, the inclination of the terrain and the large viewing angle of the satellite meant that the canopy gaps were underestimated.

In general, the transferability of the approach to other regions and sensors, or to multitemporal data sets is limited by the sensitivity of the VHR optical remote sensing data and difficult pre- 
331

processing. Stereo images, which provide 3D information, have a great potential to analyze the canopy cover in forests, but can only partly overcome these problems. For example, Hobi et al. (2015) used WorldView-2 stereo images for analyzing the canopy cover of primeval beech forests in the Ukrainian Carpathians, but failed to generate a digital surface model because the low quality of the available DTM, complex terrain and large viewing angle of the satellites. They therefore used image spectral information to delineate the canopy gaps from the stereo images, but still were only able to identify large canopy openings successfully. Rugani et al. (2013) found that the canopy gaps in Slovenian old-growth beech forests were probably underestimated in their analyses of areal stereo images. Today, LiDAR seems to be the optimal data set for analyzing the short-term dynamics of canopy gaps in detail (Vepakomma et al. 2008) and for mapping forest structure (Falkowski et al. 2009). Moreover, LiDAR may be a reliable alternative to collect reference data when using the remotely sensed data with a large coverage at low cost (e.g., imagery from the Sentinel-2 mission) for mapping of forest structure over large areas, e.g., the entire region of the Carpathians.

\subsection{Reference data}

To investigate the structure of forest stands using remote sensing data, sufficient reliable field verification sites are required and should be well geo-referenced. We were able to use both field survey data and stand map descriptions from the Ukrainian SFMPO as reference data. In our study, reference points for geo-referencing the field surveys were mostly measured beneath dense canopy cover, which made it particularly challenging to accurately link the field measurements with the WorldView-2 imagery.

The stand descriptions from the Ukrainian SFMPO provide information on the forest stand level, which was obtained using methods involving visual forest stand taxation with corresponding level of errors (Instructions for forest management planning in Ukraine 2006). Nevertheless, the correlations between the forest stand parameters, mean $\mathrm{DBH}$, density, mean height, and volume, 
357

358

359

360

361

362

363

364

365

366

367

368

369

370

371

372

373

374

375

376

377

378

379

380

381

were similar in both the stand descriptions from the SFMPO (Table 5) and those measured in the field (Table 6).

The upper part of the Borzhava river has great potential as a study area for investigating and comparing the structure of beech forests with different degrees of human impact. However, beech forests with a mean age of 70-160 years are rare because rather recent forest management has involved widespread clear-cutting and natural disturbances over large areas, e.g. windthrow or wildfire have seldom occurred. The lack of information about this particular group of beech forests may have affected the results of the correlation analysis.

\subsection{Extraction of canopy gaps}

Prior to defining forest structure types, canopy gaps were extracted for the 19 test areas and their fractions were assessed. Canopy gaps have high ecological value in the life cycle of such nonpioneer (climax) tree species as beech (Whitmore 1989), and their fraction in the forest' canopy cover is related to the development stages or degradation levels of the forest stands (McElhinny et al. 2005). Extraction of canopy gaps is either carried out during field surveys (e.g., Runkle 1982), or is based on remote sensing data and techniques (e.g., Vepakomma et al. 2008; Yang et al. 2015). We applied a simple color space transformation HLS to the WorldView-2 image bands red edge, yellow and blue, which was particularly useful for extracting gaps and tree crowns. The canopy gap fractions in the beech forests correlated significantly with the forest stand parameters mean age, mean $\mathrm{DBH}$, mean stand height, relative density, and volume for the primeval, old-growth, and middle-aged forests (Table 5). The resulting gap fractions ranged from $1.9 \%$ to $10 \%$ for old growth forests and $3.3 \%$ to $14 \%$ for primeval forests. These fractions are overall in accordance with the findings from remote sensing based studies in other European beech forests, and differ only slightly from findings from terrestrial surveys. Terrestrial surveys have found canopy gap fractions up to $5.6 \%$ in Slovenian primeval beech forests (Zeibig et al. 2005), ranging from $3.3 \%$ to $6.6 \%$ in 
382

primeval beech forests in Albania (Meyer and Schmidt 2008), and up to 16\% in virgin beech forests in Slovakia (Drößler and Lüpke 2005).

To date, canopy gaps in beech forests have been successfully extracted with remote sensing data in only a few studies. For example, Rugani et al. (2013) calculated gap fractions between $4.5 \%$ and $10 \%$ in old-growth beech forests in Slovenia based on aerial images. Getzin et al. (2014) recorded canopy gap fractions between $4.9 \%$ to $13.9 \%$ for five age-class beech-dominated forests in Germany based on manual delineation from data captured with UAV-mounted systems. In contrast, Hobi et al. (2015) analyzed WorldView-2 stereo images of the Uholka-Shyrokyi Luh primeval beech forests in the Ukrainian Carpathians and found a very low gap fraction $(0.75 \%)$.

Such large differences in the results of canopy gap extraction are due to the different definitions of gap used. The most critical parameters for defining canopy gaps are minimum gap size, minimum depth, and presence of regeneration (Runkle 1992), as well as spatial resolution, spectral threshold, viewing angles of the sensor and the sun, and topographic features when using optical remote sensing data (Hobi et al. 2015). Tree crown overlays, in particular in complex terrain, often result in underestimations of canopy gaps, or even make their extraction impossible (Rugani et al. 2013). The canopy gap fractions calculated based on optical remote sensing data, thus, cannot be compared with each other, or with those from terrestrial surveys (Rugani et al. 2013; Getzin et al. 2014; Hobi et al. 2015). This makes their transferability to other regions and other data sets problematic.

\subsection{Forest structure types}

Prior to assessing forest structure, the dynamics of the beech forest ecosystem should be analyzed in order to better understand the driving processes involved. Natural forest ecosystems are characterized by randomly distributed stand parameters over different scales, e.g., stem density, living volume, living basal area, and standing dead wood (Král et al. 2010; Alessandrini et al. 2011; Hobi et al. 2015). The spatial variability (pattern) of stand parameters in forests is often described as a spatial mixture of development stages (Korpel' 2005; Tabaku 2000). To classify the stages, 
408

409

410

411

412

413

414

various parameters are usually proposed, e.g., mean $\mathrm{DBH}$, basal area, number of living trees, and stand layers, dead wood volume, the presence of regeneration and canopy gaps, and the distribution and sizes of canopy opening.

In this study, the fraction of canopy gaps was used as a key parameter to determine forest structure types because they could be directly derived from VHR remote sensing data and were found to be correlated with the main forest stand parameters (see Table 5 and 6). Our accuracy assessment indicated that the four forest structure types, very closed, closed, medium density and low density, we identified are well chosen, with only small commission and omission errors, mostly confined to neighboring structure types (see Table 7). A few more errors were found in medium and low density structure types, which indicated that most gaps have similar frequencies. Moreover, the sample size was apparently smaller for these two structure types.

The overall accuracy of the classification of the four different structure types using VHR remote sensing data was $83 \%$, which is in accordance with other studies (e.g., Ozdemir and Karnieli 2011; Kayitakire et al. 2006). The advantages of the WorldView-2 sensor are that it has a high spectral and radiometric resolution, as well as a spatial resolution that allowed the forest structure to be assessed in sufficient detail. A key factor in this study was the use of GLCM textural features calculated on original image bands and two vegetation indices, NDVI and GNDVI. Textural features from WorldView-2 imagery have been found useful in assessing vegetation and forest structure generally (Ozdemir and Karnieli 2011), and particularly powerful as predictor variables for classifying the four forest structure types. LDA was found to be very useful for feature selection when applying logistic regression models, and superior to other approaches, e.g., that of Waser et al. (2014), for classifying tree species and tree damage, as well as forest structure types (Torresan et al. 2014).

Our four structure types correspond with one or several of the development stages in other studies. For example, a high fraction of canopy openings corresponds to our low density structure type and is typical of the decay and initial development stages identified in Korpel' (1995), and the gap and 
434

435

436

437

438

439

440

441

442

443

444

445

446

447

448

449

450

451

452

453

454

455

456

457

458

decay stages in Tabaku (2000). In contrast, the absence of canopy gaps and the presence of only small gaps corresponds to our very closed and closed structure types, respectively, and to Korpel's (1995) and Tabaku's (2000) optimal stage (including early and mid-optimum stages). Canopy openings are present (indicating the medium density forest structure type) in Tabaku's (2000) late optimum, plenter and terminal stages. The extracted very closed structure type characterizes the closed canopy cover of a middle-aged forest, corresponding to Tabaku's (2000) development stages of establishment or early optimum.

The frequency distributions of the forest structure types we found in the beech forests in our study are also similar to those reported in other studies. Meyer and Schmidt (2008) compared the fractions of development stages in managed and virgin beech forests in Germany, Albania and Slovakia, and found that the plenter and late optimal stages, which are comparable to our medium density structure type, dominated in virgin beech forests, and the optimal stage (closed structure type) in managed beech forests. The decay stage, which corresponds to the low density structure type, contained less than $20 \%$ of virgin beech forest stands and was very rare in managed beech forests (Meyer and Schmidt 2008).

\section{Conclusions and outlook}

Our novel approach to assessing the structure of potential primeval and managed beech forests at the landscape level used WorldView-2 imagery and gap fraction analysis. The spatial pattern analysis of the four proposed forest structure types based on canopy gap fractions, have a high potential to distinguish beech forests with different levels of human impact. The information we obtained on the structural variability and large-scale (forest-stand level) dynamics of natural forests will be useful for "close-to-nature" forest management planning in Ukraine. Our forest structure types were determined according to the canopy gap fractions and could be linked to specific development stages in beech forests. However, more insights into their ecologies are necessary. 
459 The limitations of our approach are mostly related to the specific properties of VHR remote sensing

460 data, which made it impossible to map the forest structure types for the entire study area. Thus, one-

461 to-one transferability of our results to other beech forest regions or using multitemporal data sets are

462 encouraged, but have to be handled with care.

463 Other sensors, e.g. LiDAR or Sentinel-2 imaging mission, may have advantages regarding these 464 limitations and replicability, and thus enable further automatization of our approach. Using LiDAR 465 data sets may reduce the need to collect costly a priori information to sample reference data, while 466 using Sentinel-2 may enable the mapping of forest structure over large areas. The usage of remote 467 sensing data with lower spatial resolution only (e.g., Sentinel-2) assumes adapting the minimal 468 canopy gap size accordingly.

469

470 Acknowledgments

471 This research was funded by the Swiss State Secretariat for Education, Research and Innovation 472 (SERI) through Swiss government excellence research scholarship (2013.0327/Ukraine/OP), and by 473 the Ministry of Education and Science of Ukraine. The preparation of the final manuscript was 474 supported by the Swiss National Forest Inventory. We are grateful to Christian Ginzler for 475 organizing the WorldView-2 imagery for the study area, Vitaliy Pukman for assistance in the field, 476 Martina Hobi for fruitful discussions, and two anonymous reviewers for their helpful comments. 477 Finally, we thank Silvia Dingwall for professional language editing. 


\section{References}

Alessandrini, A., Biondi, F., Filippo, A.D., Ziaco, E., and Piovesan, G. 2011. Tree size distribution at increasing spatial scales converges to the rotated sigmoid curve in two old-growth beech stands of the Italian Apennines. For. Ecol. Manage. 262: 1950-1962.

Barrett, F., McRoberts, R.E., Tomppo, E., Cienciala, E., and Waser, L.T. 2016. A questionnaire-based review of the operational use of remotely sensed data by national forest inventories. Remote Sens. Environ. 174: 279-289.

Brändli, U.-B., and Dowhanytsch, J. (Editors). 2003. Urwälder im Zentrum Europas. Ein Naturführer durch das Karpaten-Biosphärenreservat in der Ukraine. Birmensdorf, Eidgenössische Forschungsanstalt WSL; Rachiw, Karpaten-Biosphärenreservat. Haupt, Bern, Stuttgart, Wien. 192 S.

Chernyavskyy, M.V., and Khmil, I.V. 1998. Structural dynamics of primeval beech forest in Borzhawa. Sc. Bull. UNFU 8.1: 21-34. [in Ukrainian.]

Coburn, C.A., and Roberts, A.C.B. 2004. A multiscale texture analysis procedure for improved forest stand classification. Int. J. Remote Sensing 25(20): 4287-4308.

Commarmot, B., Brändli, U.B., Hamor, F., and Lavnyy, V. (Editors). 2013. Inventory of the Largest Primeval Beech Forest in Europe. A Swiss-Ukrainian Scientific Adventure. Birmensdorf, Swiss Federal Research Institute WSL, L’viv; Ukrainian National Forestry University; Rakhiv, Carpathian Biosphere Reserve. 69 p.

Coops, N.C., Wulder, M.A., and White, J.C. 2006. Identifying and Describing Forest Disturbance and Spatial Pattern: Data Selection Issues and Methodological Implications. In Understanding Forest Disturbance and Spatial Pattern: Remote Sensing and GIS approaches. Edited by M.A. Wulder and S.E. Franklin. CRC Press (Taylor and Francis), Boca Raton, FL, USA. pp. 31-61.

Drößler, L., and von Lüpke, B. 2005. Canopy gaps in two virgin beech forest reserves in Slovakia. J. For. Sci. 51: 446457.

Eckert, S. 2012. Improved Forest Biomass and Carbon Estimations Using Texture Measures from WorldView-2 Satellite Data. Remote Sens. 4: 810-829.

Everitt, B.S., and Dunn, G. 2001. Applied Multivariate Data Analysis. 2nd ed. Arnold Publisher, London, UK. 354 pp.

Falkowski, M.J., Evans, J.S., Martinuzzi, S., Gessler, P.E., and Hudak, A.T. 2009. Characterizing forest succession with lidar data: An evaluation for the Inland Northwest, USA. Remote Sens. Environ. 113: 946-956.

Frolking, S., Palace, M.W., Clark, D.B., Chambers, J.Q., Shugart, H.H., and Hurtt, G.C. 2009. Forest disturbance and recovery: A general review in the context of spaceborne remote sensing of impacts on aboveground biomass and canopy structure. J. Geophys. Res. 114: G00E02:27. doi:10.1029/2008JG000911.

Garbarino, M., Borgogno Mondino, E., Lingau, E., Nagel, T.A., Dukić, V., Govedar, Z., and Motta, R. 2012. Gap disturbances and regeneration patterns in a Bosnian old-growth forest: a multispectral remote sensing and ground-based approach. Ann. For. Sci. 69: 617-625.

Gitelson, A., and Merzlyak, M. 1998. Remote Sensing of Chlorophyll Concentration in Higher Plant Leaves. Adv. Space Res. 22: 689-692.

Getzin, S., Robert, S., Nuske, R.S., and Wiegand, K. 2014. Using Unmanned Aerial Vehicles (UAV) to Quantify Spatial Gap Patterns in Forests. Remote Sens. 6(8): 6988-7004.

Haralick, R. M., Shanmugan, K., and Dinstein, I. 1973. Textural features for image classification. IEEE Trans. Syst., Man, Cybern. 3(6), 610-621.

Hobi, M. L., Commarmot, B., and Bugmann, H. 2015. Pattern and process in the largest primeval beech forest of Europe (Ukrainian Carpathians). J. Veg. Sci. 26: 323-336. doi:10.1111/jvs.12234.

Hobi, M.L., Ginzler, C., Commarmot, B., and Bugmann, H. 2015. Gap pattern of the largest primeval beech forest of Europe revealed by remote sensing. Ecosphere 6: art76. 
Hosmer, D.W., and Lemeshow, S. 2000. Applied logistic regression. 2nd ed. Wiley, New York. 373 pp.

Instructions for forest management planning in Ukraine. 2006. Part 1. Fieldwork. Irpin, Ukraine. 74 pp. [in Ukrainian.]

Jawak, S.D., and Luis, A.J. 2013. A Comprehensive Evaluation of PAN-Sharpening Algorithms Coupled with Resampling Methods for Image Synthesis of Very High Resolution Remotely Sensed Satellite Data. Adv. Remote Sens. 2: 332-344.

Kayitakire, F., Hamel, C., and Defourny, P. 2006. Retrieving forest structure variables based on image texture analysis and IKONOS-2 imagery. Remote Sens. Environ. 102: 390-401.

Kennaway, T.A., Helmer, E.H., Lefsky, M.A., Brandeis, T.A., and Sherill, K.R. 2008. Mapping land cover and estimating forest structure using satellite imagery and coarse resolution lidar in the Virgin Islands. J. Appl. Remote Sens. 2(023551). doi: 10.1117/1.3063939.

Korhonen, L., Korpela, I., Heiskanen, J., and Maltamo, M. 2011. Airborne Discrete-Return LIDAR Data in the Estimation of Vertical Canopy Cover, Angular Canopy Closure and Leaf Area Index Remote Sens. Environ. 115: $1065-1080$.

Korpel', S. 1995. Die Urwälder der Westkarpaten. Gustav Fischer Verlag, Stuttgart, Jena, New York. 310 S.

Král, K., Janík, D., Vrska, T., Adam, D., Hort, L., Unar, L., and Samonil, P. 2010. Local variability of stand structural features in beech dominated natural forests of Central Europe: Implications for sampling. For. Ecol. Manage. 260: 2196-2203.

Leboeuf, A., Beaudoin, A., Forunier, R.A., Guindon, L., Luther, J.E., and Lambert, M.C. 2007. A shadow fraction method for mapping biomass of northern boreal black spruce forests using Quickbird imagery. Remote Sens. Environ. 110: $488-500$.

McElhinny, C., Gibbons, P., Brack, C., and Bauhus, J. 2005. Forest and woodland stand structural complexity: Its definition and measurement. For. Ecol. Manage. 218: 1-24.

McRoberts, R.E., Winter, S., Chirici, G., and LaPoint, E. 2012. Assessing Forest Naturalness. For. Sci. 58: 294-309.

Meyer, P., and Schmidt, M. 2008. Aspekte der Biodiversität von Buchenwäldern - Konsequenzen für eine naturnahe Bewirtschaftung. Beitr. Nordwestdt. Forstl. Versuchsanst. 3: 159-192.

Mura, M., McRoberts, R.E., Chirici, G., and Marchetti, M. 2015. Estimating and mapping forest structural diversity using airborne laser scanning data. Remote Sens. Environ. 170: 133-142.

Neter, J., Kutner, M.H., Nachtsheim, C.J., and Wasserman, W. 1996. Applied Linear Statistical Models: Regression, Analysis of Variance, Experimental Designs. Irwin. 1408 pp.

Ozdemir, I., and Karnieli, A. 2011. Predicting forest structural parameters using the image texture derived from WorldView-2 multispectral imagery in a dryland forest, Israel. Int. J. Appl. Earth Obs. Geoinf. 13: 701-710.

Pasher, J., and King, D.J. 2010. Multivariate forest structure modelling and mapping using high resolution airborne imagery and topographic information. Remote Sens. Environ. 114: 1718-1732.

Rich, R.L., Frelich, L., Reich, P.B., and Bauer, M.E. 2010. Detecting wind disturbance severity and canopy heterogeneity in boreal forest by coupling high-spatial resolution satellite imagery and field data. Remote Sens. Environ. 114: 299-308.

Richter, R., Kellenberger, T., and Kaufmann, H. 2009. Comparison of Topographic Correction Methods. Remote Sens. 1: 184-196.

Richter, K., Atzberger, C., Hank, T.B., and Mauser, W. 2012. Derivation of biophysical variables from earth observation data: Validation and statistical measures. J. Appl. Remote Sens 6(1): 063557. doi:10.1117/1.JRS.6.063557.

Roth, C. 1932. Beobachtungen und Aufnahmen in Buchen-Urwäldern der Wald-Karpaten. Schweiz. Z. Forstwes. 83(1): $1-13$. 
566

567

568

569

570

571

572

573

574

575

576

577

578

579

580

581

582

583

584

585

586

587

588

589

590

591

592

593

594

595

Rouse, J.W., Haas, R.H., Schell, J.A., and Deering, D.W. 1973. Monitoring Vegetation Systems in the Great Plains with ERTS. In Proceedings of the Third ERTS Symposium: NASA SP-351. NASA, Washington, DC, USA. pp. 309317.

Rugani, T., Diaci, J., and Hladnik, D. 2013. Gap Dynamics and Structure of Two Old-Growth Beech Forest Remnants in Slovenia. PLoS ONE 8(1): e52641. doi:10.1371/journal.pone.0052641.

Runkle, J.R. 1982. Patterns of Disturbance in Some Old-Growth Mesic Forests of Eastern North-America. Ecology 63: $1533-1546$

Smirnov, N. 1939. On the estimation of the discrepancy between empirical curves of distribution for two independent samples. Moscow, Univ. Bull. Math. 2(2): 16 p.

Tabaku, V. 2000. Struktur von Buchen-Urwälder in Albanien im Vergleich mit deutschen Naturwaldreservaten und Wirtschaftswäldern. Dissertation, Göttingen, Deutschland.

Torresan, C., Strunk, J., Zald, H.S.J., Zhiqiang, Y., and Cohen, W.B. 2014. Comparing statistical techniques to classify the structure of mountain forest stands using CHM-derived metrics in Trento province (Italy). Eur. J. Remote Sens. 47: 75-94.

Uhl, E., Metzger, H.G., and Seifert, T. 2006. Dimension und Wachstum von solitären Buchen und Eichen. Jahrestagung der Sektion Ertragskunde des Deutschen Verbands Forstlicher Forschungsanstalten in Staufen.

Updike, T., and Comp, C. 2010. Radiometric Use of WorldView-2 Imagery: Technical Note. Digital Globe. pp. 1-16.

Vepakomma, U., St-Onge, B., and Kneeshaw, D. 2008. Spatially explicit characterization of boreal forest gap dynamics using multitemporal lidar data. Remote Sens. Environ. 112: 2326-2340.

Waser, L.T., Küchler, M., Jütte, K., and Stampfer, T. 2014. Evaluating the potential of WorldView-2 data to classify tree species and different levels of ash mortality. Remote Sens. 6: 4515-4545.

Watt, A.S. 1947. Pattern and process in the plant community. J. Ecol. 35(1/2): 1-22.

Whitmore, T.C. 1989. Canopy gaps and the two major groups of forest trees. Ecology 70(3): 536-538.

Wood, E.M., Pidgeon, A.M., Radeloff, V.C., and Keuler, N.S. 2012. Image texture as a remotely sensed measure of vegetation structure. Remote Sens. Environ. 121, 516-526.

Yang, J., Jones, T., Caspersen, J., and He, Y. 2015. Object-Based Canopy Gap Segmentation and Classification: Quantifying the Pros and Cons of Integrating Optical and LiDAR Data. Remote Sens. 7: 15917-15932.

Zeibig, A., Diaci, J., Wagner, S. 2005. Gap disturbance patterns of a Fagus sylvatica virgin forest remnant in the mountain vegetation belt of Slovenia. For. Snow Landsc. Res. 79(1/2): 69-80. 
Table 1. Acquisition parameters of the WorldView-2 scene.

Data/time (UTC)

Sun azimuth $\left(^{\circ}\right)$

17 Jun 2012, 9:59:27

Mean Sun elevation $\left(^{\circ}\right)$

164.8

Mean InTrack view angle $\left(^{\circ}\right)$

64.3

Mean CrossTrack view angle $\left(^{\circ}\right)$

19.3

$-3.5$

19.7

Spatial Resolution (m)

Radiometric Resolution (bits per pixel)

Spectral bands wavelengths $(\mu \mathrm{m})$

Panchromatic: 0.5, Multispectral: 2.0

11

Panchromatic: $450-800$,

Coastal: 400-450, Blue: 450-510, Green: 510-580, Yellow:

585-625, Red: 630-690, RedEdge: 705-745, NIR1: 770-

895, NIR2: $860-1040$ 
Table 2. Characteristics of the beech forest groups.

\begin{tabular}{|c|c|c|c|c|c|c|c|}
\hline \multirow{2}{*}{$\begin{array}{l}\text { Beech forest groups } \\
\text { (mean stand age) }\end{array}$} & \multirow{2}{*}{$\begin{array}{c}\text { Numbers } \\
\text { of test } \\
\text { areas }\end{array}$} & \multirow{2}{*}{$\begin{array}{c}\text { Total area of } \\
\text { test areas } \\
\text { (ha) }\end{array}$} & \multirow[b]{2}{*}{ Slope $\left({ }^{\circ}\right)$} & \multicolumn{4}{|c|}{ Main stand parameters ${ }^{\dagger}$} \\
\hline & & & & $\begin{array}{l}\text { mean DBH } \\
(\mathrm{cm})\end{array}$ & $\begin{array}{c}\text { mean } \\
\text { height }(\mathrm{m})\end{array}$ & $\begin{array}{c}\text { relative } \\
\text { density }(\%)\end{array}$ & $\begin{array}{l}\text { volume } \\
\left(\mathrm{m}^{3} / \mathrm{ha}\right)\end{array}$ \\
\hline $\begin{array}{l}\text { Primeval forests } \\
\text { (220 years) }\end{array}$ & $1-3$ & 56.11 & $25-30$ & $52.9-60.9$ & $30-34$ & $60-62$ & $389-439$ \\
\hline $\begin{array}{l}\text { Old-growth forests } \\
\text { (160-190 years) }\end{array}$ & $4-12$ & 93.56 & $20-30$ & $44.9-56.9$ & $30-34$ & $49-70$ & $308-533$ \\
\hline $\begin{array}{l}\text { Middle-aged forests } \\
\quad(35-60 \text { years })\end{array}$ & $13-19$ & 67.55 & $20-30$ & $11.8-24.5$ & $10.7-23.6$ & $80-100$ & $140-420$ \\
\hline
\end{tabular}

${ }^{\dagger}$ Data from the Ukrainian State Forest Planning Organization (SFMPO) 
Table 3. Image features used in the study with the total number of features given in brackets. Spectral features (10)

WorldView-2 original bands (C, B, G, Y, R, RE, NIR1, NIR2)

Vegetation indices (NDVI, GNDVI)

\begin{tabular}{lc}
\hline mean $=\sum_{i j=0}^{n-1} p(i, j)$ & Contrast $=\sum_{n=0}^{n-1} n^{2}\left\{\sum_{i=1}^{n} \sum_{j=1}^{n} p(i, j)\right\}$ \\
variance $=\sum_{i=0}^{n-1} p_{i j}(i-\mu)^{2}$ & correlation $=\frac{\sum_{i} \sum_{j}(i j) p(i, j)-\mu_{x} \mu_{y}}{\sigma_{x} \sigma_{y}}$ \\
homogeneity $=\sum_{i} \sum_{j} \frac{1}{1+(i-j)^{2}} p(i, j)$ & dissimilarity $=\sum_{n=0}^{n-1} n\left\{\sum_{i=1}^{n} \sum_{j=1}^{n} p(i, j)\right\}$ \\
second moment $=\sum_{i} \sum_{j}\{p(i, j)\}^{2}$ & entropy $=-\sum_{i} \sum_{j} p(i, j) \log (p(i, j))$
\end{tabular}
$\sum 80$ of all features

where $p(i, j)$ is a normalized GLCM matrix element, $\mu$ the pixel values weighted mean, and $\sigma$ the pixel values weighted variance. 
Table 4. Examples of the four structure types in the beech forests. The canopy gap fraction is shown for the $50 \times 50 \mathrm{~m}$ grid cell. The boundaries of the canopy gaps are depicted with a grey line. In very closed stands, no gaps are extracted.

\begin{tabular}{lcccccc}
\hline Canopy gap fraction & $0 \%$ & $0.1 \%-10 \%$ & $10.1 \%-20 \%$ & $>20 \%$ \\
\hline
\end{tabular}


Table 5. Spearman correlation coefficients for the canopy gap fractions and forest stand parameters of the 19 test areas. Stand parameters were derived from the stand descriptions of the Ukrainian SFMPO.

\begin{tabular}{|c|c|c|c|c|c|}
\hline Stand parameters & $\begin{array}{l}\text { Gap } \\
\text { fraction }\end{array}$ & Mean age & Mean DBH & Mean height & $\begin{array}{l}\text { Relative } \\
\text { density }\end{array}$ \\
\hline Mean age & $0.75^{* * *}$ & & & & \\
\hline Mean DBH & $0.74^{* * *}$ & $0.86^{* * *}$ & & & \\
\hline Mean height & $0.71^{* * *}$ & $0.64^{* *}$ & $0.81^{* * *}$ & & \\
\hline Relative density & $-0.65^{* *}$ & $-0.76^{* * *}$ & $-0.71^{* * *}$ & $-0.65^{* * *}$ & \\
\hline Volume & $0.47^{*}$ & 0.45 & $0.58^{* *}$ & $0.74^{* * *}$ & -0.18 \\
\hline
\end{tabular}

${ }_{* * *}^{* * *}$ Correlation is significant at 0.001 level (2-tailed)

${ }^{* *}$ Correlation is significant at 0.01 level (2-tailed).

* Correlation is significant at 0.05 level (2-tailed). 
Table 6. Spearman correlation coefficients for the canopy gap fractions and forest stand parameters of the 8 field survey areas calculated from the field measurements.

\begin{tabular}{lcccc}
\hline Stand parameters & Gap fraction & Mean DBH & Mean height & Tree density \\
\hline Mean DBH & $\mathbf{0 . 7 9}$ & & & \\
Mean height & $\mathbf{0 . 4 3}$ & $0.81^{*}$ & & \\
Tree density & $\mathbf{0 . 7 1}$ & $-0.75^{*}$ & -0.62 & -0.14 \\
Volume & $\mathbf{0 . 6 2}$ & 0.67 & 0.29 & \\
\hline
\end{tabular}

${ }^{*}$ Correlation is significant at 0.05 level (2-tailed). 
Table 7. Confusion matrix of the structure type classification using multinomial logistic regression.

\begin{tabular}{|c|c|c|c|c|c|c|}
\hline \multirow{2}{*}{ Reference data } & \multicolumn{5}{|c|}{ Classification } & \multirow{2}{*}{$\begin{array}{c}\text { User's } \\
\text { accuracy }\end{array}$} \\
\hline & very closed & closed & medium density & low density & $\sum$ & \\
\hline very closed & 165 & 22 & 1 & 0 & 188 & 0.88 \\
\hline closed & 25 & 274 & 24 & 1 & 324 & 0.85 \\
\hline medium density & 0 & 29 & 128 & 7 & 164 & 0.78 \\
\hline low density & 0 & 0 & 10 & 30 & 40 & 0.75 \\
\hline$\sum$ & 190 & 325 & 163 & 38 & 716 & - \\
\hline Producer's accuracy & 0.87 & 0.84 & 0.79 & 0.79 & - & - \\
\hline Overall accuracy & \multicolumn{6}{|c|}{0.83} \\
\hline Cohen's kappa coefficient & \multicolumn{6}{|c|}{0.75} \\
\hline
\end{tabular}




\section{Figure captions}

Figure 1. Location (left) and the WorldView-2 scene (right) of the study area in the Ukrainian Carpathians with the locations of the test areas and field surveys.

Figure 2. Flowchart for classifying the forest structure types in the beech forest using WorldView-2 satellite imagery, field surveys and forest stand maps.

Figure 3. Example of a regular $50 \times 50 \mathrm{~m}$ grid used to subdivide the canopy cover of the forest in a test area into non-overlapping parts.

Figure 4. Frequency distributions of the gap fractions in the canopy cover in the primeval (A), oldgrowth (B), and middle-aged beech forests (C), and the forest structure types (D).

Figure 5. Predictive mapping of forest structure types in the study area with the test areas marked. Slopes with an exposition between $120^{\circ}-220^{\circ}$ were excluded. 

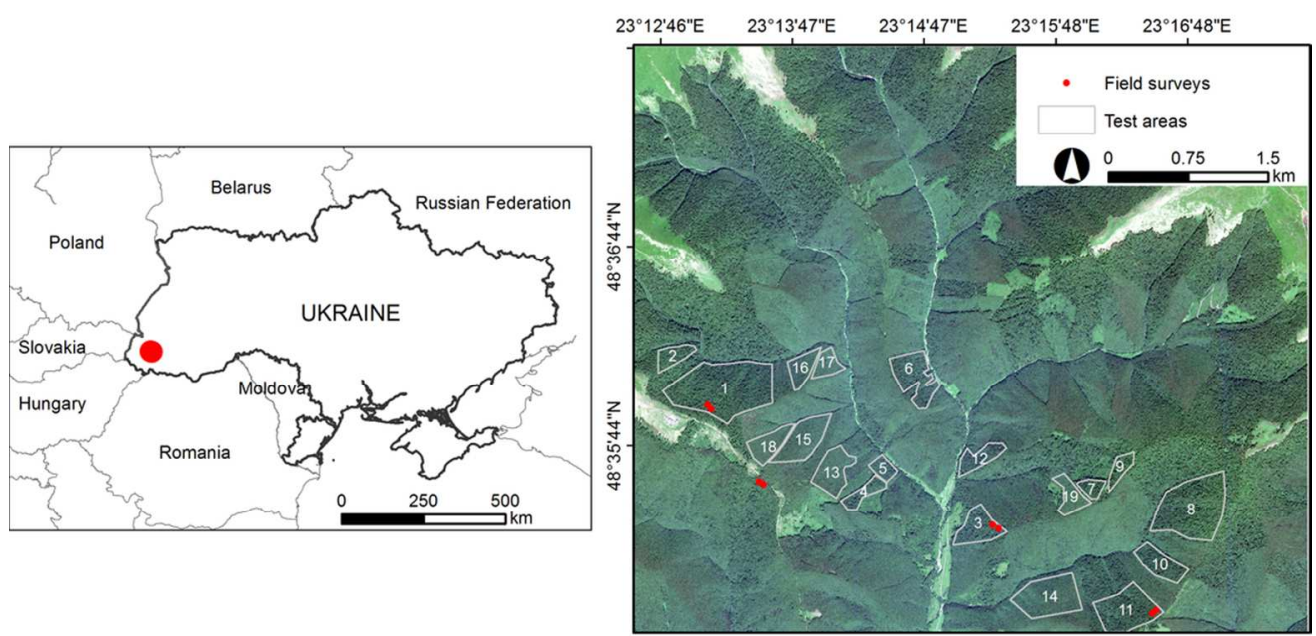

Figure 1. Location (left) and the WorldView-2 scene (right) of the study area in the Ukrainian Carpathians with the locations of the test areas and field surveys.

Figure 1

$98 \times 47 \mathrm{~mm}(300 \times 300 \mathrm{DPI})$ 


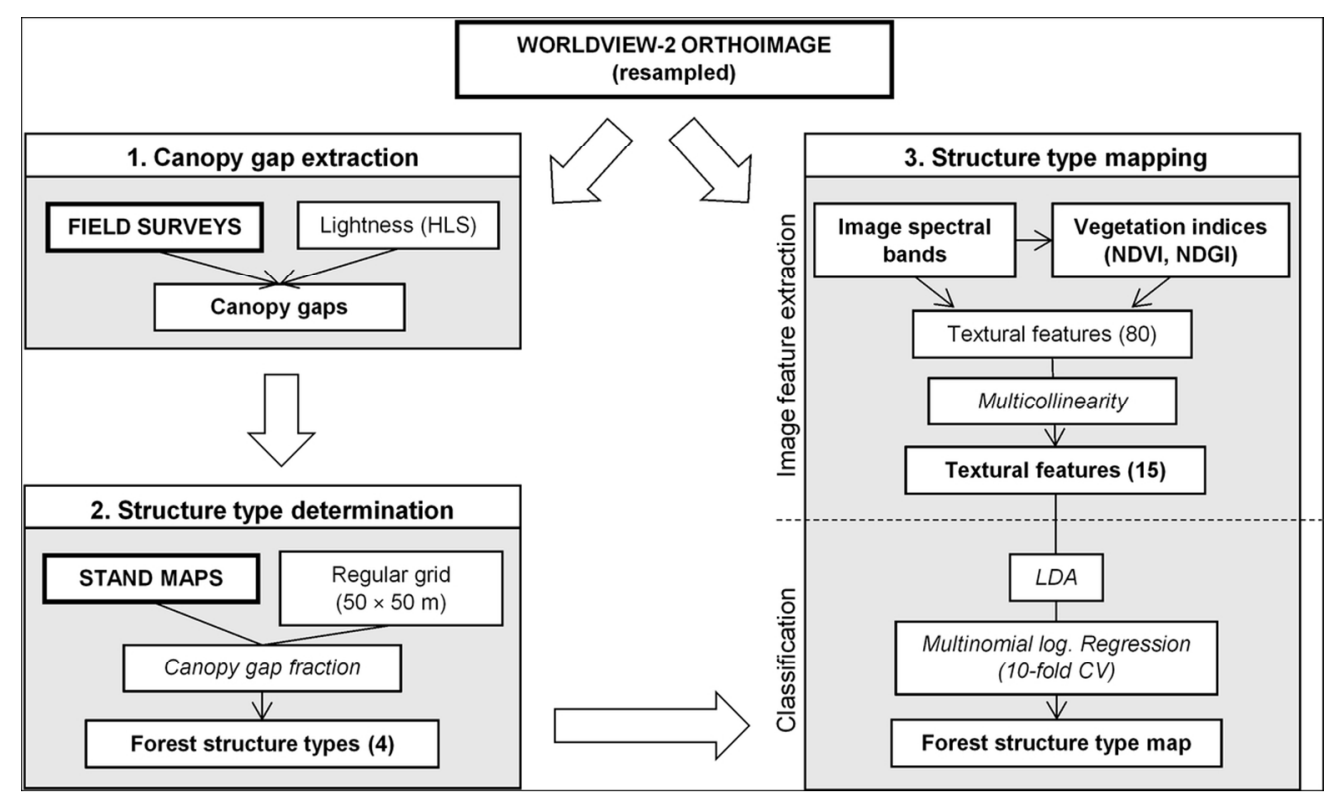

Figure 2. Flowchart for classifying the forest structure types in the beech forest using WorldView-2 satellite imagery, field surveys and forest stand maps.

Figure 2

$109 \times 64 \mathrm{~mm}(300 \times 300 \mathrm{DPI})$ 


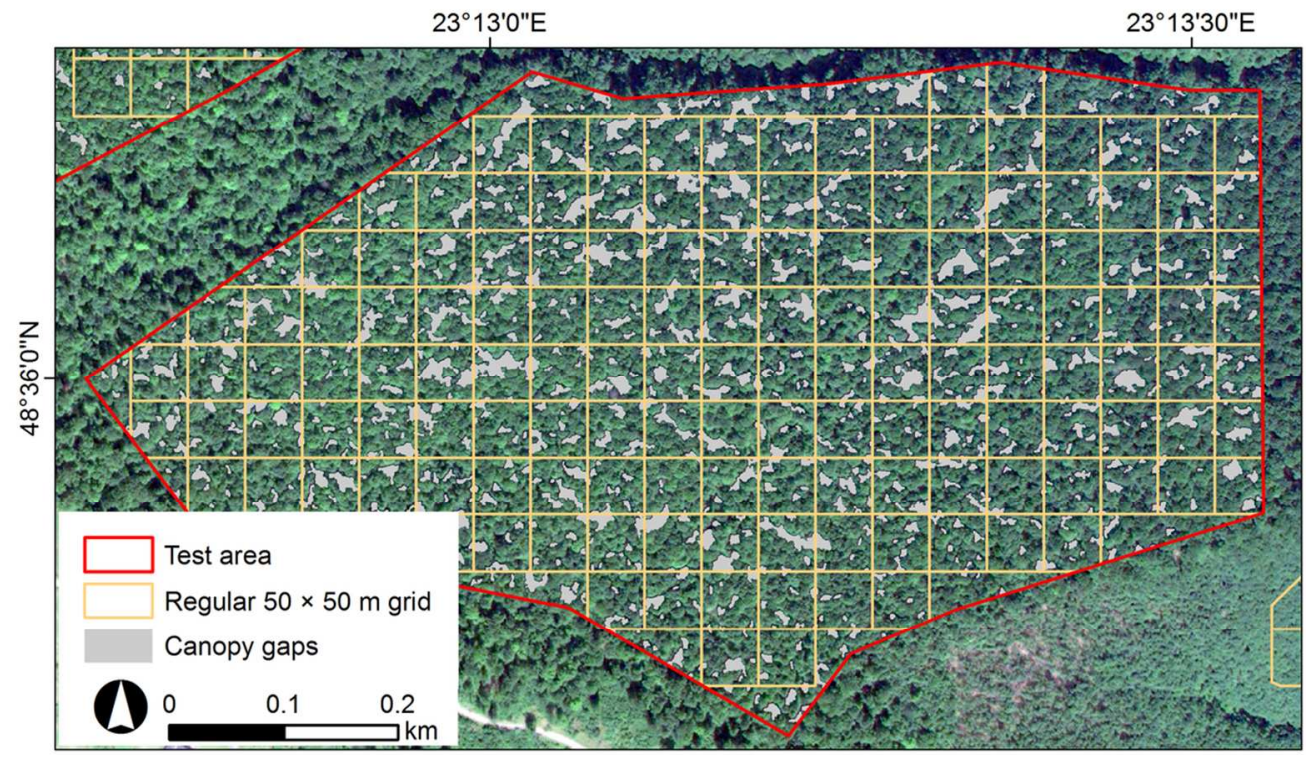

Figure 3. Example of a regular $50 \times 50 \mathrm{~m}$ grid used to subdivide the canopy cover of the forest in a test area into non-overlapping parts.

Figure 3

$102 \times 59 m m(300 \times 300$ DPI $)$ 

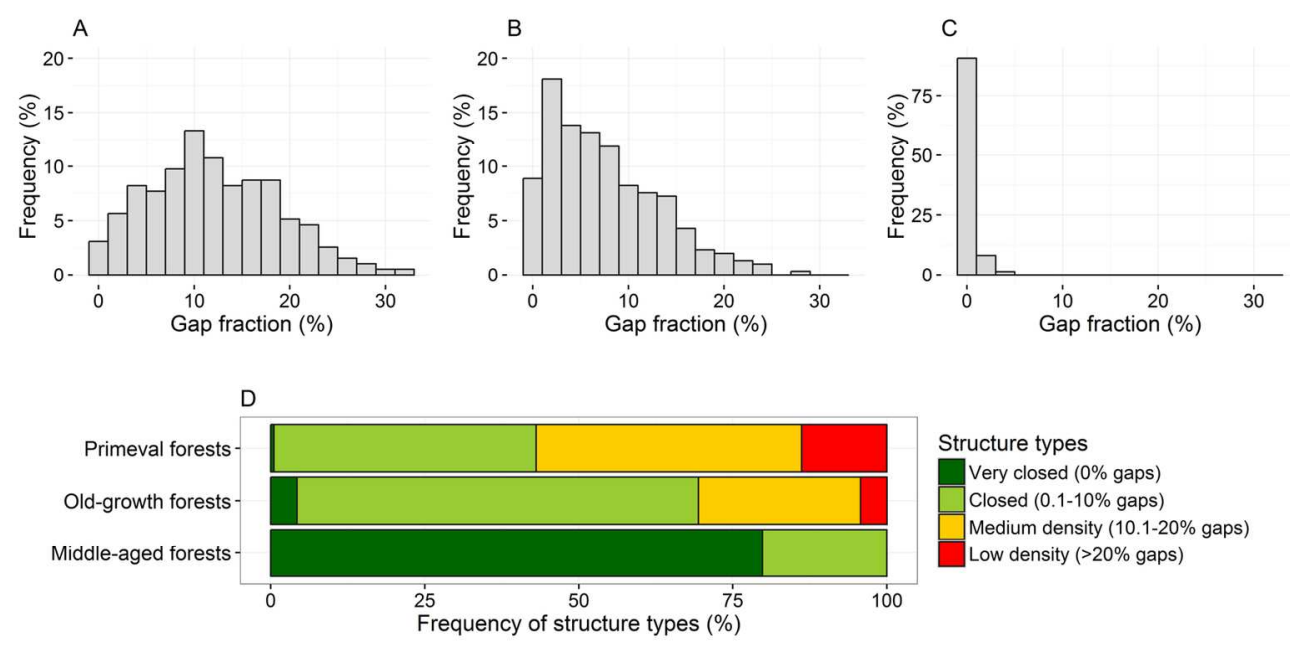

Figure 4. Frequency distributions of the gap fractions in the canopy cover in the primeval (A), old-growth (B), and middle-aged beech forests (C), and the forest structure types (D).

Figure 4.

$149 \times 76 \mathrm{~mm}(300 \times 300 \mathrm{DPI})$ 


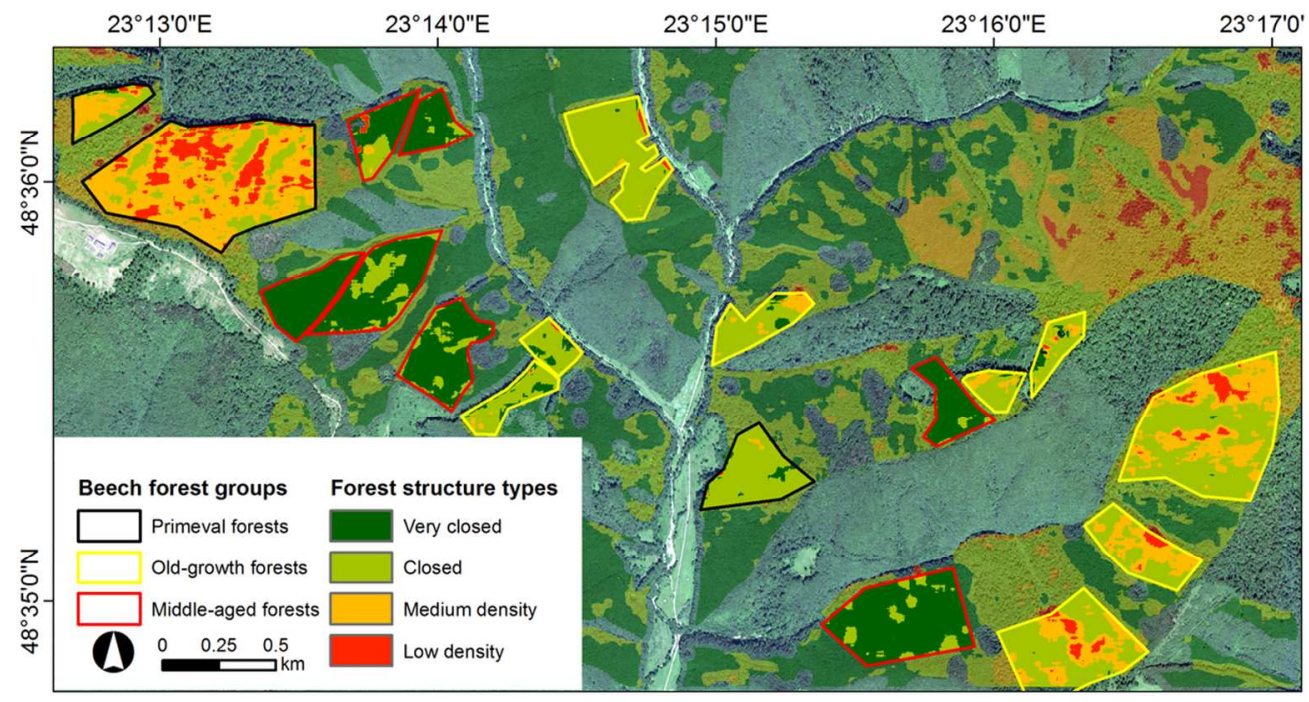

Figure 5. Predictive mapping of forest structure types in the study area with the test areas marked. Slopes with an exposition between $120^{\circ}-220^{\circ}$ were excluded.

Figure 5

$102 \times 55 \mathrm{~mm}(300 \times 300 \mathrm{DPI})$ 